\title{
Creative Learning Through Google Classroom in History Learning During the Covid-19 Pandemic
}

\author{
Euis Nela ${ }^{1 *}$, Nana Supriatna ${ }^{2}$ \\ ${ }^{1}$ Student of the Master of History Education Program, UPI Postgraduate School \\ ${ }^{2}$ Lecturer in the Master of History Education Program, UPI Postgraduate School \\ *Email: euisnela2@gmail.com
}

\begin{abstract}
This research is motivated by creativity which has not been a priority in learning. In fact, teacher's creativity can actually be a support to grow and develop learning skills of students. Being innovative and creative in using technology and information media is a required skill in the teaching and learning process especially during the situation of Covid-19 Pandemic. The purpose of this research is to find out specifically about creative learning through Google Classroom in history learning. This study uses the literature review method, namely by tracing readings in the form of books, journals, research reports and news as well as other relevant and published sources from 2015 to 2020 . The results from these sources found that with the phenomenon of Covid-19 pandemic, creative learning models through Google Classroom can have an effective role in developing learning abilities, especially social sciences lessons, make it easier for teachers and students to carry out teaching and learning activities, and assist learning activities to be done anywhere and anytime. Creative learning through Google Classroom also supports the 21 st century learning strategies so that students are able to develop creative thinking skills and the skills to produce ideas or works.
\end{abstract}

Keywords: learning, creative, creativity, google classroom.

\section{INTRODUCTION}

Technology and information in the industrial era 4.0 has grown rapidly so that it has a big impact on the world of education, even very important because science and information are also always evolving. Therefore, the role of technology in education in the midst of the Covid-19 pandemic is pivotal. This situation forces teachers and students to adapt and be able to take advantage of the technology. The development of technology is expected to be used in learning during the pandemic, so that the learning process can be integrated in the use of technology. Assistance in the use of technology is needed to be able to access distance learning (PJJ) / online to facilitate the learning process.
According to Law number 20 of 2003 [1] on National Education System, Distance Education (PJJ) is a separate education between teachers and students; the learning process uses various sources with the help of technology and other media. Meanwhile, Nadiem Makarim as the Minister of Education and Culture said that PJJ is a necessity, including the use of information and communication technology [2]. The implementation of the PJJ certainly demands the readiness of both teachers and students. In Circular Letter Number 4 of 2020 [3], the Ministry of Education and Culture of the Republic of Indonesia regarding the Implementation of the Covid19 Emergency Education Policy, it also explains about PJJ including: 1) Learning from home is carried out to provide meaningful learning experiences for students; 2) focused on life skills education; 
3) Activities and tasks may vary, according to individual interests and conditions; 4) Evidence or learning activities are given a qualitative response without being required to give a quantitative score / value.

The learning process based on the 2013 curriculum prioritizes learning that emphasizes the activeness of students, learning independently by utilizing information and communication technology to improve efficiency and effectiveness. It means teachers must be able to provide opportunities for students to build their own creative and innovative knowledge [4]. Moreover, the Covid-19 pandemic has affected various dimensions such as economic, political, social, and psychological. These dimensions are continually being addressed in studies to better prepare the education system in a new period of human history [5]. The new period is a change in normal behaviour coupled with the application of health protocols, to prevent the transmission of Covid-19 or better known as the new normal. The new normal is also applied to the world of education, including the new normal curriculum, with the aim of the curriculum developing preparedness competencies among students. In terms of curriculum content, there is a challenge of integrating or reducing some of the contents. Therefore, teachers are instructed to be able to develop appropriate models, media and learning methods, so that the teaching and learning process continues to create educative interactions during the PJJ process.

During the PJJ process, teachers can use technology as a creative, innovative, interesting and not monotonous learning medium so that students are interested and remain enthusiastic in participating in teaching and learning activities. Hence, teachers are required to continue to develop their creativity in the learning process, as stated by [6] that creative teachers must be able to take advantage of something that is available in the environment around students as an interesting learning medium. However, according to Abduh Zen in [7] teachers as educators are generally still conventional in the learning process, boring and unimaginative. Teachers including history teachers have not shown their creativity in learning. This is not only obtained from the findings of various students, but also based on the author's experience meeting with students in teaching and learning activities. Even some history teachers revealed that learning history has not been attractive to students because of the lack of creativity in learning. However, according to [8] with creativity, learning objectives will be achieved optimally through fun ways that include three domains of knowledge, attitudes and skills. This is in line with the teacher's efforts in designing and implementing history learning with a scientific approach so that classical problems in history learning can be resolved, expository becomes student-centred, the phenomenon of boredom becomes fun learning.

Creative learning with the help of digital technology such as Google Classroom is assumed to be able to foster creative thinking and skills in producing ideas or students' work. This is as stated by [9] that the creative learning model has a positive effect on the achievement of 21 st century skills of students. According to him, creative learning that has the most influence on learning skills and innovation is the Imagine and Reflect stages. The most influential on the tools to work is the Create and Experiment stages while the way of working is strongly influenced by the Share stage. Griffin, P, McGaw, B. \& Esther, C. in [10] identified four groups of $21 \mathrm{st}$ century skills, namely ways of thinking, ways of working, ways for working and living in the world. The essence of the way of thinking is to make something, this prioritizes creativity and innovation and emphasizes that creativity must be a priority in learning.

Looking the reality in the field, it is known that creativity has not been a priority in learning whereas creativity can actually be a support for growing and developing learning skills, innovating and being creative in using technology and information media in the learning process. Learning creativity in the perspective of history teachers has not been optimal because learning has not used technology assistance that can help students digest the subject matter creatively, interactively, productively, effectively, inspiringly, constructively, and pleasantly. Based on this, researchers feel the need to find out some literature on learning that can stimulate students to generate and increase creativity. In this case, the researcher will specifically examine the literature on creative learning through the Google classroom in history learning. This literature review purpose to find out specifically about creative learning through the Google classroom in history learning during the Covid-19 pandemic.

\section{RESEARCH METHOD}

This study uses a literature review, which is compiled through reading searches in the form of books, journals, research reports and media news as well as other relevant sources that have been published from 2015 to 2020 . The source search is carried out using the keywords learning, creative, 
creativity, Google Classroom and creative learning. The data obtained in the search are then presented in a descriptive narrative to explain and describe the purpose of writing.

\section{RESULTS AND DISCUSSION}

\subsection{Creativity}

\subsubsection{The Meaning of Creativity}

Creativity according to [11] is something that is universal and is a characteristic of aspects of the world of life around us marked by creating something that did not exist before and wasn't done by someone or there is a tendency to create something. Meanwhile, according to Alex Osborn in [12] said that creativity is an applied art. Creativity is an art that is taught to others and vice versa, other people can also learn creativity. This is supported by research evidence showing that every creative process can be taught and learned. [13] Suggests that the definition of creativity focuses on five creative thinking habits, including: (1) Curiosity; (2) Persistent; (3) Imaginative; (4) Collaborative; (5) Discipline.

According on the explanation, it was decuded that creativity is a high-level ability of an individual to produce a product, idea that is different from the existing ones, or to connect some existing ones and make them something new. Creativity produces a new perspective on an existing problem or situation so that creativity is a cognitive activity so that creativity is able to produce new products, ideas or novelty. Teachers as agents of change are given the opportunity to design and develop the quality of history learning into a creative and innovative educational process.

The creativity of teachers in learning, especially history teachers is very necessary. It aims to make students interested in history lessons. History teachers are required to have creativity in all fields related to history learning, as well as the use of various historical learning models, methods and media. Teachers as educators can help students to master 21 st century skills, namely by reforming the learning process. The 21 st century skills consist of creativity and innovation, critical thinking and problem solving skills, collaboration, and communication. These skills must be mastered by students in order to face the challenges of the times.

\subsubsection{Types of creativity}

Rhodes [12] suggests that there are four dimensions of creativity called "The Four P's of Creativity", namely person, process, product, and press:

Person: Creativity is an expression of the uniqueness of the individual in interactions with his environment. From a unique personality, it is hoped that new ideas can emerge as well as innovative products. So that teachers must be able to appreciate the personal uniqueness and talents of students.

Process: To develop creativity, students need to be given the opportunity to engage themselves creatively. The process of keeping busy creatively can be done without the need to always or too quickly demand creative products.

Press (pressure) / encouragement: Creativity will be realized if there is encouragement and support from himself (internal motivation), namely creative ability which means the ability to break ordinary thinking. Encouragement and support must also come from the environment, because creativity can develop in a supportive environment.

Product: Meaningful creative products will arise from the talents and creative personal traits, as well as with encouragement (internal and external). Creative products can be classified into three categories, including: novelty, resolution and elaboration \& synthesis.

From the explanation above, it can be concluded that creativity has 4 (four) types, namely person, process, press, and product.

\subsubsection{Characteristics of creativity}

Torrance describes the characteristics of creativity in the form of fluency, flexibility, originality and elaboration [10]. Fluency here is fluency in responding to every problem. Flexibility is a characteristic inherent in someone who is flexible and able to adapt to change. Originality is the ability that is owned to cultivate and develop something that is effective and useful (usefulness) in accordance with the situation and conditions to elaborate or broaden horizons.

Meanwhile, according to Boden, 2004; \& Craft, 2001 [14] the main characteristics or characteristics of creativity are: (1) Originality, which is a thought that is intrinsically impermanent, has a new perspective of thinking from the point of view of observing a problem; (2) comprehensiveness, namely 
a way of thinking that is able to provide complementary analysis of a problem with different perspectives and levels, and is able to form new theories to be integrated into the elements of thought as a thought process to reach a conclusion; (3) Difference (divergence), namely how to solve problems using more than one solution mindset, with the ability to deduce several different information.

The characteristics of creative individuals according to some experts include having characteristics that are rich in ideas or tend to be fluent in generating ideas, sensitive to problems, having mental flexibility, having different thoughts from other people in general, being able to redefine an object or concept that might be has been known for a long time, has complex behavioural styles and characteristics, is humorous and has the ability to accept conflict and tension [12].

\subsection{Creative Learning}

\subsubsection{Definition of Creative Learning}

According to Supriatna \& Maulidah [10] Creative Learning is one element of creative pedagogy apart from creative teaching and teaching for creative (teaching to build creativity). Creative Learning according to Lin, 2011; Selkrig \& Keamy, 2007 in Supriatna \& Maulidah [10] is a learning that allows students to develop curiosity, dare to try, explore, desire to experience, and have a sense of pleasure, given the opportunity to do positive, spontaneous things and given the opportunity to collaborate in developing imagination and thinking in their own way. Therefore, teachers should be able to develop creative and imaginative learning to develop student creativity.

Meanwhile, according to Budiningsih Creative learning is a learning model that emphasizes students to be creative in the learning process [15]. Not only students, but teachers also have to be creative so that positive energy can be felt by students. Creative learning has many advantages, one of the advantages is that teachers and students will be given the freedom to express and be creative (active).

In general, creative learning is a learning that requires teachers to motivate and bring out student creativity during the learning process. Creative learning must be able to stimulate students to generate creativity, both in the context of creative thinking and in the context of creative doing something [16]. The creativity of teacher learning in the classroom is as follows: (1) Formulating creative learning objectives in accordance with the basic competencies and level of students' thinking abilities; (2). Using a variety of learning resources that follow development trends in the digital era and making use of historical places; (3). Modifying and combining creative learning methods tailored to the goals of the curriculum and the potential of students; (4). Using creative learning media that can be reached and found around the student environment; (5). Implementation of the learning process with creative learning models and methods; (6). Conduct learning evaluations by giving students unique tasks such as making scrapbooks, puzzles, vlogs, time lines, and crossword puzzles [6]

In Creative learning, students will be given more roles, compared to teachers, this is intended to develop learning activities towards a better direction. The teacher only acts as the director, while the students are the players. As directors, teachers can use various methods and techniques in learning [15]. According to Ling Creative Learning can be distinguished from non-creative learning [10]. Uncreative learning places more emphasis on teacher authority to make students not creative (learning by authority). However, learning by authority also allows students to learn which leads to creative learning, if the teacher provides more space for students to ask various questions, seek their own answers, play roles and so on.

Creative learning during the Covid-19 pandemic must have a fully aware and sensitive concept, teachers must be creative in creating a good learning process and foster empathy, students listen to the learning process, teachers note new discoveries in student works and provide reflection and provide reinforcement. Therefore, creative learning as learning can encourage students' interest in learning, can encourage students to use their imagination and engage their natural curiosity, experiment and test ideas, apply mixed media and interdisciplinary approaches, and see old problems in new visions.

\subsubsection{Characteristics and Impact of Creative Learning}

The characteristics of creative learning are imagining what might happen, exploring ideas, leaving options open, reflecting on ideas critically, questioning and challenging, making connections and seeing relationships, as well as actions and results, Ofsted in Lucas \& Anderson [13]. Meanwhile, the impact of creative learning on individual students includes (1) Creative learning is very likely to help learners be more creative; (2) creative learning helps students to learn better, because it has a visible and 
positive impact on students' personal development, and on their preparation for life outside of school; (3) Creative learning contributes to increasing student achievement; (4) creative learning contributes to various positive results. In addition, Jindal-Snape, et al in [13] found that a conducive creative learning environment contributes to beneficial results including increased student motivation and involvement, students feel personal success, increased levels of trust, increased resilience to social and emotional development, increased attendance, creative learning activities appear to be able to engage parents in a variety of useful ways.

A teacher must have the capability and loyalty, that is, must have the ability in the field of science being taught, and have good theoretical skills about teaching, from planning, implementation to evaluation and have teacher loyalty, which is loyal to teacher tasks that are not only in the classroom, but before and after class. Teachers must also have creativity in managing their learning. Creative history teachers are required to be more innovative in learning so that they are able to condition students by considering different learning styles. That is why, history teachers can use models, methods and media that allow them to be applied in teaching and learning activities.

\subsubsection{How to Improve Creative Learning}

According to Lucas and Anderson [13] in his research, how to improve creative learning is more likely to occur in some learning environments than others, including: (a) Teachers' beliefs and perceptions about their own creativity and how they can be encourage creativity in their students; (b) A series of teacher behaviours have been identified, including helping students to withstand pressure, to adjust to an openness or orientation, or to allow time for ideas to be incubated; (c) More broadly than his work in the field of education.

One way to improve creative learning is to use the Creative Learning Cycle proposed by Sawyer, R.K in [9] which is a learning approach consisting of drawing, creating, playing, sharing, reflecting and reimagining activities. This learning is also known as the Mitchell Learning Spiral. According to him, this learning method is considered appropriate and in harmony to be used in 21 st century learning, so that it can help students develop creative thinking skills. Meanwhile, according to Resnick, $M$ in [9] Mitchell Resnick's Learning Spiral is an iterative learning process to strengthen creative thinking skills techniques in problem solving. There are five stages of Creative Learning known as the Mitchell Learning Spiral.

The five stages of Creative Learning are as follows: 1) Imagine. The imagine stage is thinking about what you want to do or exchanging ideas. The imagine stage is the process of thinking about what will be done or known as the brainstorming process; 2) Create. The create stage is the stage where students translate the ideas generated from the imagine stage into product form; 3) Play. The play stage is the process of trying new creations or products and checking whether the product is running well or not. Play is a learning stage involving a fun experimentation process, playing with material, trying new things, testing boundaries and taking repeated risks; 4) Share. The share stage is the process of showing the creations that have been made to others and seeing what they think about the creations, then incorporating the process into the creative learning process; 5) Reflect. The reflect stage is the process of thinking about what has been learned from the experience of the Imagine, Create, Play and Share stages then return to the Imagine process to create new ideas again after going through the process of creative activities. Reflectivity is a process that encourages students to discuss and ask questions, this activity can be part of each individual's evaluation of something that students have thought and made.

Based on the stages of the creative learning cycle, it can be concluded that creative learning is a learning model that can support learning in the 21 st century. With the current social phenomenon, namely the Covid-19 pandemic, this learning model is considered capable of generating ideas and solutions in solving problems from experiences that have been experienced by someone based on their experiences. Whatever the approach used, the researchers and practitioners agree that enhancing creative learning requires a conscious focus on multiple areas. The creativity of history teachers is very important in learning, especially during PJJ because students are very easily get bored and tired. With creativity, the teacher can understand the character and learning style of each student. Therefore, the teacher must be able to condition the class well so that learning can run effectively by using model, media and methods that are more creative and innovative according to the needs of students in teaching and learning activities.

\subsection{Google Classroom}

According to Pilli [17] Learning Management System (LMS) is the most important system for 
learning, which is used to provide course information for students. LMS contains many tools such as announcements, discussion groups, forums, content, tasks, messages, and file delivery. Learning Management System (LMS) which is widely used as an online learning medium during the Covid-19 pandemic, one of which is Google Classroom.

\subsubsection{Definition Of Google Classroom}

Google Classroom is part of the Google for Education service. Google for Education is very helpful in the teaching and learning process in schools because it has several services, such as Google Classroom, G-Mail, Google Calendar, GDrive, and Google Docs. Google Classroom is feasible to be implemented in Indonesia, because it has the same structure as existing learning management system [18]. Google classroom is a virtual classroom that can be used for educational purposes to help find solutions to the difficulties experienced in making paperless assignments [19]. Google classroom is one of the media that makes it easy to distribute learning materials and questions and can be used as a means of assessing the work of students and interacting with other users [20]. Meanwhile, Liu, et al in Vasanth and Sumathi [21] argue that Google Classroom is a free web service learning environment used for e-learning.

The same thing was also stated that Google Classroom is a free learning application developed by Google for the use of the education system with the aim of making it easier for teachers to plan, implement and assessing students' assignments or work in a paperless approach, while encouraging the process of sharing learning materials between students and teachers by forming an online learning environment community [22-24].

Google Classroom is effective in developing learning skills as shown in a study by KM Dicicco which suggests that Google Classroom can be effective in social learning and can improve student learning abilities [25]. Thus, Google Classroom is an application from Google for Education to create virtual classrooms. This application helps teachers and students in carrying out learning activities.

\subsubsection{Utilization of Google Classroom as a Learning Media}

Learning media can add to the appearance of the material to be more attractive so that it is expected to increase the motivation and interest of students. Students can also be distracted to focus on following the material presented, so that it is also hoped that the effectiveness of learning will increase. The implementation of Google Classroom as a learning media as a whole is quite effective, making it easier for teachers to create, share and group each assignment without using paper [26]. The Google Classroom platform has applications integrated within Google itself such as Google Sheets, Google Slides and others. Google Classroom also has links to other applications such as Quizizz, Kahoot, Quizlet, Plickers, Ed-Puzzle and so on which involve the application's function as a social network, as a material sharing tool, as an interactive learning board, as data storage and as preparation for strengthening training (Embi , MA, 2013; Yusoff AFM, et al. 2019; Abdullah, MAR \& Hussin. S, 2019 in [27]). Google Classroom provides many facilities, so it is easier for teachers and students to carry out learning activities. This learning is not only in the classroom, but also outside the classroom because by accessing Google Classroom students can learn anywhere and anytime [20].

Google Classroom was developed using information media in the form of video and audio in accordance with pedagogical technology aspects, so that Google Classroom was able to create an interesting and fun learning atmosphere. Thus, it is hoped that the quality of history learning will be better so that the application of Google Classroom media will create a virtual classroom that has a more effective creative and communicative environment for teachers and students. All applications in Google Classroom have their own strengths to support the effectiveness of the application emphasizing 21st century learning strategies The $4 \mathrm{C}$ concept is communication, collaboration, critical thinking and creativity which makes students able to cultivate creative thinking and creative products, students will also be able to develop life and career skills to compete globally.

\subsection{History Learning Media}

Learning media is a tool in learning activities that is used to stimulate the teaching and learning process so that the learning objectives are achieved as planned. The use of learning media assistance can facilitate and improve the learning process because the media can clarify the delivery of messages and information. Learning media can direct and increase students' attention so that it can generate learning motivation and can overcome senses, space and time. [28]. Meanwhile, according to A. Malik in [29] that learning media are everything that can be used to convey messages in the form of learning materials, so that they can stimulate the attention, thoughts, 
feelings and interests of students to achieve learning goals.

Learning media is anything that can be used to trigger thoughts, feelings, attention and abilities or skills of students so that they can encourage a pleasant learning process. Learning media can be used to help teachers create interesting learning. Learning media must be chosen by taking into account the effectiveness and learning objectives to be achieved. History learning media is a tool to reduce the use of students' verbalism, so that students know historical events not only as memorizing material. By using media, the achievement of the objectives of learning history is more optimal and meets the expectations. One of the multimedia is elearning, which is the use of learning media using the internet, to send a series of solutions that can increase knowledge and skills and creativity. Thus, the selection of google classroom media is expected to increase student creativity, learning objectives can be achieved, and the media itself can be more effective.

\subsection{History Lessons During the COVID-19 Pandemic}

Learning history during the Covid-19 pandemic requires teachers to use a method of delivering material that is short, clear, and quite easy to understand by students. History teachers must be open so that online and offline learning is not monotonous [30]. Meanwhile, according to [31], suggests that history learning must be able to adapt according to the situation that occurs. As the government's appeal that learning during the Covid19 pandemic can be inserted knowledge about the pandemic. Learning during a pandemic prioritizes the use of information communication technology and learning based on the independence of students' learning so that learning practices have changed drastically. E-education and e-learning with internet facilities have been fully operational because they are driven by the Covid-19 pandemic situation [32].

Learning is a very important key in any educational endeavour. The learning process has an important role as an effort to improve the quality of education. In order to create creative and meaningful learning, of course, you must optimize learning with the help of creative, varied, effective and contemporary learning media. One of the media that can be used during the Covid-19 pandemic by teachers in carrying out the learning process is Google Classroom.

\section{CONCLUSION}

Based on the results of a study of several relevant literatures that has been published in 2015 to 2020, it shows that creative learning through Google Classroom is one of the reforms that teachers can do during the Covid-19 pandemic, because creative learning is a learning model that can support 21st century learning strategies, namely the concept of $4 \mathrm{C}$ communication, collaboration, critical thinking and creativity which makes students able to cultivate creative thinking skills and skills to produce ideas or students' work, and can encourage students to use creativity, imagination and involve their natural curiosity. With the Covid-19 pandemic phenomenon, creative learning models using Google Classroom can have an effective role in developing learning abilities, especially history lessons as part of social education, make teaching and learning activities easier for teachers and students and support the learning activities to be carried out anywhere and anytime.

\section{SUGGESTION}

The creativity of history teachers is very important in learning, especially during PJJ in the Covid-19 pandemic situation, because students are very easily get bored and tired. In the future, it is hoped that history teachers will have creativity so that they can understand the character and learning style of each student. Therefore, teachers must be able to manage classes, both real / offline classes and virtual / online classes so that learning can run effectively. Teachers are also expected to use more creative and innovative models, methods and media according to the needs of students in teaching and learning activities both offline and online. In the future, it will be better if creative learning through Google Classroom is accompanied by the creativity of teachers so that they can easily improve creative thinking skills and the ability to produce ideas or students' work. By so doing, the students' creativity will increase and learning objectives will be achieved optimally and problems in learning history can be resolved, including learning become more studentcentred and it will become more fun.

\section{ACKNOWLEDGMENTS}

The author would like to thank Prof. Dr. Nana Supriatna, M.Ed and Dr. Leli Yulifar, M.Pd as lecturers in the History Education Masters Program at the Indonesian University of Education who have helped and provided guidance and insights. 


\section{REFERENCES}

[1] Undang-Undang Nomor 20 Tahun 2003 Tentang Sistem Pendidikan Nasional. Jakarta: Kemendikbud

[2] Tolok, A.D: Pandemi Covid-19, Mendikbud: Saatnya Manfaatkan Teknologi dengan Optimal [online]. Bisnis.com. (2020, 02 Juli).

[3] Surat Edaran Kemendikbud Nomor 4 Tahun 2020 tentang Pelaksanaan Kebijakan Pendidikan Masa Darurat Covid-19. Jakarta: Kemendikbud

[4] Nela. E.: Implementasi Teknologi Digital untuk Meningkatkan Karakter Kejujuran dan Motivasi Belajar Peserta Didik Dalam Pembelajaran Sejarah. HISTORIA: Jurnal Pendidik dan Peneliti Sejarah Vol 4, No 1 (2020).

[5] Cahapay, M.B.: Rethinking Education in the New Normal Post-COVID-19 Era: A Curriculum Studies Perspective. AQUADEMIA, 4(2), ep. 20018. (2020)

[6] Umami. N. \& Purwaningsih. S.M.: Kreativitas Pembelajaran Sejarah Di Kelas (Guru Sejarah Alumni Pendidikan Provesi Guru). AVATARA, e-Journal Pendidikan Sejarah Volume 6, No. 2. (2018).

[7] Abrar.: Kreatifitas Pembelajaran: Perspektif Guru Sejarah Provinsi DKI Jakarta. Seminar Nasional Sejarah ke 4 Jurusan Pendidikan Sejarah Universitas Negeri Padang. Hal. 254265. (2019).

[8] Yulifar, L.: Teacher's Effort in Improving Historical Writing Skill by Presenting Historian as Resources Person on Historical Learning. Advances in Social Education and Humanities Research 1st International Conference of Innovation in Education (ICoIE): Atlantis Press, 1(178), 230-234. (2018).

[9] Putro, B.L, dkk.: Creative learning model as implementation of curriculum 2013 to achieve 21st century skills. Journal of Physics: Conference Series. $1280 \quad$ (2019) 032034 doi:10.1088/1742-6596/1280/3/032034. (2019).

[10] Supriatna, N \& Maulidah. N.: Pedagogik Kreatif, Menumbuhkan Kreativitas Dalam Pembelajaran Sejarah dan IPS. Bandung: PT Rosdakarya. (2020).
[11] Mulyasa. E.: Menjadi Guru Profesional, Menciptakan Pembelajaran Kreatif dan Menyenangkan. Bandung: PT Remaja Rosdakarya. (2019).

[12] Rhodes, M.: An Analysis of Creativity. The Phi Delta Kappan, 42(7), 305-310. from http://www.jstor.org/stable/20342603. (1961).

[13] Lucas, B. \& Anderson. M.: Creative Learning in Schools: what it is and why it matters A Rapid Evidence Scan. Dusseldorp Forum. (2015).

[14] Nastity, S.A.: Perbedaan Tingkat Kreativitas Ditinjau dari Persepsi Anak Terhadap Pola Asuh Orangtua Siswa SD Muhammadiyah 4 Surabaya. Skripsi. Universitas Airlangga. (2016).

[15] Hasanah. M \& Tihawariyun.: Pengaruh Penggunaan Metode Pembelajaran Creative Learning Terhadap Hasil Belajar Siswa Pada Konsep Sistem Ereksi Manusia Di SMA Negeri 2 Beutong Kabupaten Nagan Raya. Prosiding Seminar Nasional Biotik 2018. (2018).

[16] Suwandayani. dkk.: Perencanaan Pembelajaran Creative Learning dalam mata kuliah profesi keguruan. Elementa: Jurnal Prodi PGSD STKIP PGRI Banjarmasin. Vol. 1, No. 1, Halaman:917. (2019).

[17] Pilli. O.: LMS Vs. SNS: Can Social Networking Sites Act as a Learning Management Systems. American International Journal of Contemporary Research, Vol. 4, No. 5. (2014).

[18] Pradana, D. B.P \& Harimurti, R.: Pengaruh Penerapan Tools Google Classroom pada Model Pembelajaran Project Based Learning terhadap Hasil Belajar Siswa. Jurnal IT-Edu. Volume 02 Nomor 01, 59-67. (2017).

[19] Iskandar, dkk. Aplikasi Pembelajaran TIK. Yayasan Kita Menulis. (2020).

[20] Millatana, M. E.: Peningkatan Prestasi Belajar Matrik dengan Pembelajaran Blanded Learning Berbantuan Google Classroom di Kelas XI IPS 1 SMA Negeri 7 Yogyakarta. Jurnal Ide Guru, Vol.4 No.2. (2019).

[21] Vasanth. S \& Sumathi, C.S.: Learning Management Systems through Moodle and Google Classroom for Education. Advances in Research 21(10): 32-37, 2020; Article no.AIR.61324 ISSN: 2348-0394, NLM ID: 101666096. (2020). 
[22] Susilo, J., Kartono \& Mastur, Z.: Analysis Metacognition and Communication Mathematics in Blended Learning Use Google Classroom. Unnes Journal of Mathematics Education Research, 8(1), 72-83. (2019).

[23] Wijaya, A.: Analysis of factors affecting the use of google classroom to support lectures. Kertas kerja yang dibentangkan di 5th International Conference on Information Technology and Engineering Application Palembang-Indonesia. (2016).

[24] Dash, S.: Google classroom as learning management system to teach Biochemistry in a medical school. Biochemistry and Molecular Biology Education, 1-4. (2020).

[25] Al-Maroof, R.A.S. \& Al-Emran, M.: Students Acceptance of Google Classroom: An Exploratory Study using PLS-SEM Approach. International Journal of Emerging Technologies in Learning (iJET), eISSN: 1863-0383, DOI: https://doi.org/10.3991/ijet.v13i06.8275. (2018).

[26] Soni. dkk Optimalisasi Pemanfaatan Google Classroom Sebagai Media Pembelajaran Di SMK Negeri Bangkinang. Jurnal Pengabdian Untuk Mu NegeRI. Vol.2 No.1. ISSN: 25500198. (2018).

[27] Kaviza. M.: Kesediaan Murid Terhadap Penggunaan Aplikasi Google Classroom Sebagai Platform Pembelajaran Sejarah. Malaysian Journal of Social Sciences and Humanities (MJSSH), Volume 5, Issue 4, 108 115 ,

DOI: https://doi.org/10.47405/mjssh.v5i4.397. (2020).

[28] Pujihastuti, S.: Manajemen Pengembangan Media Pembelajaran Pendidikan Agama Islam Pada Siswa Kelas VII Di MTsN Jatinom Kabupaten Klaten Tahun Pelajaran 2016/2017. [Tesis]. (2018).

[29] Sumiharsono, R \& Hasanah, H.: Media Pembelajaran. Jember; CV. Pustaka Abadi. (2017).

[30] Susanti. S. Praktik Pembelajaran Sejarah Pada Masa Pembelajaran Jarak Jauh (PJJ). HISTORIS: Jurnal Kajian, Penelitian \& Pengembangan Pendidikan Sejarah. Vol. 5, No. 2, Hal. 102-106. (2020).

[31] Amboro, K.: Kontekstualisasi Pandemi Covid19 dalam Pembelajaran Sejarah. Yupa: Historical Studies Journal P-ISSN: 2541-6960;
E-ISSN: 2549-8754 Vol. 3 No. 2, 90-106. (2019)

[32] Pujilestari, Y.: Dampak Positif Pembelajaran Online Dalam Sistem Pendidikan Indonesia Pasca Pandemi Covid-19. ADALAH: Buletin Hukum \& Keadilan., 4(1), 49-56. https://doi.org/https://doi.org/10.15408/adalah.v 4i1.15394. (2020). 